\title{
PENINGKATAN HASIL BELAJAR SISWA KELAS I MADRASAH IBTIDAIYAH NEGERI 6 TAPIN MELALUI MODEL PEMBELAJARAN KOOPERATIF TIPE MAKE A MATCH
}

\author{
Rismarini \\ Madrasah Ibtidaiyah Negeri 6 Tapin \\ Email : rismarini@gmail.com \\ Website : https://jurnal.uin-antasari.ac.id/index.php/ptkpend/index \\ Received: Juni 2019; Accepted: Agustus 2019; Published: Agustus 2019
}

\begin{abstract}
This study aims to study the improvement of learning outcomes after learning with the Make a Match type cooperative learning model. This research method uses Classroom Action Research with two cycles with steps namely planning, action, observation and reflection. The subjects of this study were class I MIN 6 Tapin. Data collected is the result of observations of the implementation of learning and learning outcomes tests. Data analysis using descriptive quantitative techniques. The results of the study discussed the learning outcomes with classical completeness in the first cycle of the first meeting of $63.63 \%$, the second meeting $68.18 \%$, the second cycle of the first meeting was $77.27 \%$ and the second meeting was 95.45\%. The data obtained shows that the Make a Match cooperative learning model can improve student learning outcomes in thematic material about my family.
\end{abstract}

Keywords : make a match; learning outcomes; cooperative model.

\begin{abstract}
ABSTRAK
Penelitian ini bertujuan untuk mengetahui peningkatkan hasil belajar setelah dilaksanakan pembelajaran dengan model pembelajaran kooperatif tipe Make a Match. Metode penelitian ini menggunakan Penelitian Tindakan Kelas dengan dua siklus dengan langkah yaitu perencanaan, pelaksanaan tindakan, observasi dan refleksi. Subjek penelitian ini adalah siswa kelas I MIN 6 Tapin. Data yang dikumpulkan adalah hasil observasi pelaksanaan pembelajaran dan tes hasil belajar. Analisis data menggunakan teknik kuantitatif deskriptif. Hasil penelitian menyebutkan bahwa hasil belajar dengan ketuntasan klasikal siklus I pertemuan pertama sebesar $63,63 \%$, pertemuan kedua $68,18 \%$, siklus II pertemuan pertama sebesar 77,27\% dan pertemuan kedua 95,45\%. Data-data yang diperoleh menunjukkan bahwa model pembelajaran kooperatif tipe Make a Match dapat meningkatkan hasil belajar siswa dalam materi tematik tentang keluargaku.
\end{abstract}

Kata Kunci : make a match; hasil belajar; model kooperatif

\section{PENDAHULUAN}

Undang-undang Nomor 20 Tahun 2003 tentang Sistem Pendidikan Nasional pada pasal 3 menegaskan bahwa pendidikan nasional berfungsi mengembangkan kemampuan dan membentuk watak serta peradaban bangsa yang bermartabat dalam rangka mencerdaskan kehidupan bangsa, bertujuan untuk berkembangnya potensi peserta didik agar menjadi manusia yang beriman dan bertaqwa kepada Tuhan Yang
Maha Esa, berakhlak mulia, sehat, berilmu, cakap, kreatif, mandiri dan menjadi warga negara yang demokratis serta bertanggung jawab. Pendidikan yang baik akan menghasilkan sumber daya manusia yang baik pula. Bidang pendidikan merupakan andalan dan harapan bagi munculnya sumber daya manusia yang mempunyai kualitas dan daya saing yang tinggi, bertanggung jawab, dan mengerti tugas dan fungsinya sebagai anak bangsa. 
Pendidikan sekolah merupakan ujung tombak untuk merealisasikan tujuan pendidikan nasional tersebut. Melalui proses belajar mengajar yang dilaksanakan semua siswa memperoleh berbagai ilmu pengetahuan umum, pengetahuan agama, dan berbagai keterampilan yang diperlukan kelak ketika mereka menjalani kehidupan ditengah-tengah masyarakat. Pendidikan adalah suatu bidang kehidupan yang sangat dinamis. Inovasi kurikulum pendidikan merupakan aspek penting untuk selalu diupayakan peningkatan dan relevansinya dengan tuntutan perkembangan zaman. Kebijakan implementasi Kurikulum 2013 merupakan kebutuhan yang sangat mendesak untuk mempersiapkan generasi milineal penerus perjuangan bangsa. Akan tetapi kebijakan ini belum sepenuhnya siap dilaksanakan di tataran institusi dan para praktisi pendidikan. Analoginya adalah seperti orang yang sedang melakukan perjalanan dengan mengendarai sebuah mobil, pada saat sedang asyik menikmati perjalanan tersebut tiba-tiba mereka harus berganti kendaraan dan berganti jalan yang harus dilalui. Proses pendidikan dan pembelajaran dengan kurikulum KTSP 2006 yang belum tuntas dan atau berhasil mencapai tujuan pendidikan tiba-tiba harus beralih kepada materi tematik yang akan jadi ciri khas Kurikulum 2013. Pembalajaran diklasifikasikan dengan materi pembelajaran tematik di kelas rendah (kelas I sampai dengan III), dan materi berdasarkan mata-mata pelajaran secara terpisah pada kelas tinggi (kelas IV sampai dengan VI).

Hal ini tentu menimbulkan berbagai permasalahan dan kendala yang tidak ringan, tidak hanya dari faktor guru tetapi juga unsur pendidikan yang lain. Permasalahan yang muncul dari faktor guru adalah bahwa guru telah terbiasa mengajarkan materi-materi pelajaran secara terpisah melalui mata-mata pelajaran, sedangkan dalam Kurikulum 2013 kebanyakan guru masih meraba-raba tentang pembelajaran tematik ini. Penyebab lanjutan adalah karena guru tidak atau belum mendapatkan sosialisasi yang intensif tentang materi, strategi dan metode pembelajaran dalam Kurikulum 2013. Adapun faktor di luar guru adalah ketersediaan sarana pembelajaran dan sumber belajar yang belum mendukung untuk implementasi Kurikulum 2013 secara keseluruhan.

Disisi lain Kurikulum 2013 pada jenjang pendidikan sekolah dasar merupakan kurikulum berbasis kompetensi, menggunakan pendekatan saintifik dengan suatu proses ilmiah yang mengembangkan sikap, keterampilan dan pengetahuan siswa. Dalam pasal 11 Permendikbud No. 57 Tahun 2014 ditegaskan bahwa pembelajaran tematik-terpadu merupakan muatan pembelajaran dalam mata pelajaran Sekolah Dasar/Madrasah Ibtidaiyah yang diorganisasikan dalam tema-tema. Defenisi tentang tematik ini dikemukakan pula oleh Webb dan Pearson yang menyatakan bahwa model tematik merupakan kesatuan tematema yang memuat gagasan pengajaran dan mengintegrasikan beberapa topic.

Penerapan pembelajaran tematik dianggap cocok karena merupakan model pembelajaran terpadu yang menggunakan tema-tema untuk mengaitkan beberapa muatan pelajaran sehingga dapat memberikan pengalaman bermakna bagi siswa. Disamping itu pembelajaran tematik lebih menekankan pada penerapan konsep belajar sambil melakukan sesuatu (learning by doing) sesuai materi yang sedang dihadapi. Selain dua aspek ciri khas tersebut Rusman (2014: 258) merincikan karakteristik pembelajaran tematik bahwa pembelajaran yang dilaksanakan hendaknya (1) berpusat pada siswa; (2) memberikan pengalaman langsung; (3) pemisahan mata pelajaran tidak begitu jelas; (4) menyajikan konsep dari berbagai mata pelajaran; (5) bersifat fleksibel; (6) hasil pembelajaran sesuai dengan minat dan kebutuhan siswa, dan (7) menggunakan prinsip belajar sambil bermain dan menyenangkan.

Agar pembelajaran tematik itu berjalan bagus dan berhasil maksimal guru membuat perencanaan tentang beberapa 
indikator pengalaman belajar yang akan berpengaruh langsung terhadap aktivitas dan hasil belajar siswa. Langkah ini penting mengingat hasil belajar merupakan tujuan akhir yang menjadi barometer keberhasilan atau pencapaian tujuan dari proses belajar yang telah dilaksanakan.

Sarana pendukung yang disediakan dalam rangka implementasi Kurikulum 2013 ini adalah Buku Guru dan Buku Siswa Pembelajaran tematik. Kedua buku pegangan tersebut menjadi panduan dalam melasksanakan kegiatan belajar mengajar. Muatan buku sudah menyerap dan menampilkan sedapat mungkin memotivasi atau membangkitkan semangat siswa untuk mempelajari, menggali, dan mengembangkan informasi kompetensi yang dikehendaki.

Pembelajaran direncanakan sedemikian rupa agar siswa dapat menemukan konsep sendiri berdasarkan pengetahuan awal sehingga akan lebih bermakna. Hal sebagaimana dikemukakan oleh Trianto (2006: 11) yang menjelaskan bahwa proses pembelajaran yang aktif, kreatif, inovatif, efektif, dan menyenangkan dapat dilakukan oleh siswa yang disiapkan oleh pendidik melalui kegiatan-kegiatan yang menarik, menyenangkan untuk membangkitkan rasa ingin tahu, memotivasi siswa untuk berpikir kritis, dan menemukan hal-hal baru.

Mengacu pada pelaksanaan Kurikulum 2013, pada Tahun Pelajaran 2017/2018 MIN 6 Tapin sudah berusaha melaksanakan pembelajaran tematik secara keseluruhan dari Kelas I sampai dengan VI, diantaranya untuk merealisasikan visi MIN 6 Tapin, yaitu "terwujudnya seluruh warga madrasah yang beriman, bertaqwa, berakhlak mulia, kreatif dan berprestasi, sehat jasmani dan rohani, meguasai ilmu pengetahuan dan teknologi. Sedangkan misinya adalah: (1) mengoptimalkan proses dan hasil pembelajaran dan bimbingan di madrasah (2) Mengoptamilisasi penatausahaan yang berbasis 3 tepat (tepat data, tapat waktu dan tapat sasaran), (3) meningkatkan mutu pelayanan pendidikan dan pengajaran yang berbasis agama, (4) mengembangkan koordinat dan kemitraan pendidikan madrasah. Visi dan misi ini berusaha dicapai oleh guru kelas I MIN 6 Tapin dengan berusaha menggunakan berbagai strategi dan model pembelajaran.

Berdasarkan hasil refleksi bersama guru kelas I MIN 6 Tapin dapat diidentifikasi beberapa permasalahan sebagai berikut: (1) proses pembelajaran tematik yang diterapkan masih terpisahpisah (tidak secara utuh), (2) siswa cenderung malas bertanya meskipun sebenarnya kurang memahami materi yang disampaikan guru, (3) pembelajaran cenderung mengacu pada Buku Guru dan Buku Siswa meskipun terkadang tidak sesuai, (4) kesulitan memadukan antar muatan pelajaran dalam pembelajaran tematik, dan (5) siswa cenderung memperoleh materi dari aktivitas membaca dan mendengar belum sampai aktivitas melakukan. Hal tersebut berdampak pada perolehan hasil belajar Penilaian Akhir Semester 1 siswa kelas I yang masih ada di bawah Kriteria Ketuntasan Minimal (KKM), yaitu dari 20 siswa hanya 13 siswa $(65,00 \%)$ yang tuntas pada pelajaran tematik tema 4 Keluargaku, dan masih ada 7 orang siswa $(35,00 \%)$ yang belum tuntas.

Berpijak dari fenomena tersebut diatas, penulis termotivasi untuk melakukan penelitian untuk mencari alternative solusi agar pembelajaran di kelas I MIN 6 Tapin ini dapat meningkat lebih baik. Penulis menerapkan model pembelajaran koperatif tipe Make a Match dalam kegiatan pembelajaran tematik di kelas I. Penerapan model Make a Match ini diharapkan mampu mendorong siswa untuk lebih aktif dalam kegiatan belajarnya sehingga proses dan hasil belajar tematik siswa dapat dicapai secara lebih maksimal. Hal ini sebagaimana disinyalir oleh Huda (2013: 253) bahwa model Make a Match akan dapat meningkatkan aktivitas belajar siswa, baik secara kognitif maupun fisik karena terdapat unsur permainan dan menjadikan model ini lebih menyenangkan. Sisi positif lainnya juga dikemukakan oleh Lie (2010) 
bahwa pembelajaran model Make a Match melibatkan siswa sepenuhnya karena guru disini berlaku sebagai pembimbing jalannya diskusi dalam mencocokkan jawaban siswa. Keterlibatan siswa jelas terlihat dari bagaimana usaha siswa dalam mencari jawaban yang sesuai dengan pertanyaan. Keterlibatan siswa dalam model Make a Match dapat dikatakan sebagai pengalaman belajar siswa itu sendiri". Pengalaman belajar merupakan salah satu upaya siswa untuk terus berkembang dan memperluas pengetahuan siswa. Karakteristik model Make a Match memiliki hubungan yang erat dengan karakteristik siswa yang gemar bermain.

Penelitian yang mendukung penelitian ini adalah penelitian yang dilakukan Wibowo dan Marzuki (2015) yang menunjukkan bahwa pembelajaran

\section{METODE PENELITIAN}

Penelitian ini menggunakan metode Penelitian Tindakan Kelas (PTK) yang diterapkan pada kelas I MIN 6 Tapin. Penelitian ini menggunakan dua siklus, dengan langkah-langkah perencanaan, pelaksanaan tindakan, observasi dan refleksi pada setiap siklusnya (Arikunto, Suharjo dan Supandi, 2014).

Penelitian dilaksanakan pada bulan September 2018 dengan subjek penelitian adalah siswa kelas I MIN 6 Tapin. Teknik pengumpulan data menggunakan observasi saat pembelajaran dan tes tema keluargaku. Data yang diperoleh berupa data aktivitas guru dan siswa, serta hasil belajar siswa. Data hasil belajar yang dilihat merupakan data hasil belajar dalam satu kelompok. Data-data tersebut dianalisis secara deskriptif dan disesuaikan dengan kriteria pada tabel berikut.

Tabel 1. Kriteria Aktivitas Guru dan Siswa

\begin{tabular}{|c|c|}
\hline Skor & Krieria \\
\hline $0-20$ & Sangat kurang \\
\hline $21-40$ & Kurang \\
\hline $41-60$ & Cukup \\
\hline $61-80$ & Baik \\
\hline $81-100$ & Sangat Baik \\
\hline
\end{tabular}

dengan menerapkan model Make a Match dapat meningkatkan motivasi belajar siswa, terbukti dengan meningkatnya hasil belajar siswa dan persentasi ketuntasan belajar pada siklus II dibandingkan dengan siklus I.

Selain itu, hasil penelitian Rusminawati dan Mediatati (2017) menunjukkan terjadinya peningkatan motivasi dan hasil belajar siswa pada siklus II, dibandingkan dengan siklus I. Data yang diperoleh menunjukkan 7 siswa tidak tuntas (29\%) dan 17 siswa tuntas (71\%), sedangkan pada siklus II diperoleh sebanyak 22 siswa tuntas $(92 \%)$ dan 2 siswa tidak tuntas $(8 \%)$. Berdasarkan ulasan tersebut, mka perlu dilakukan penelitian untuk mengetahui peningkatan hasil belajar siswa kelas I MIN 6 Tapin dengan model pembelajaran make a match.

Sedangkan untuk hasil belajar ditinjau dari rata-rata hasil kognitif siswa minimal 70 dengan ketuntasan belajar siswa sebesar $75 \%$ dari jumlah seluruh siswa yang ada.

\section{HASIL DAN PEMBAHASAN}

Hasil penelitian diuraikan dalam tahapan yang berupa siklus-siklus pembelajaran yang dilakukan dalam proses belajar mengajar di kelas. Dalam penelitian ini pembelajaran dilakukan dalam dua siklus sebagaimana pemaparan berikut ini:

\section{Siklus I dan II \\ a. Perencanaan}

Kegiatan yang dilaksanakan pada perencanaan ini adalah:

1) Membuat skenario, yaitu Rancangan Pelaksanaan Pembelajaran Pembelajaran (RPP) dengan menggunakan model pembelajaran kooperatif Make a Match siklus I pada materi (1) anggota keluargaku. (2) anggota keluargaku, Siklus II (1) Keluarga besarku, dan (2) Kebersamaan dalam keluarga.

2) Menyusun lembar observasi untuk melihat bagaimana proses pembelajaran menurut skenario kegiatan belajar mengajar untuk guru dan keaktifan siswa. 
3) Menyiapkan media pembelajaran.

4) Mendesain alat evaluasi untuk mengukur /menentukan keberhasilan tindakan kelas melalui soal tes.

5) Menetapkan observer yaitu Ibu $\mathrm{Hj}$. Prihatin Surti Musdiyah, S.Pd.Sd

\section{b. Pelaksanaan Tindakan}

\section{Pertemuan 1}

Kegiatan pembelajaran yang dilakukan pada tahap siklus I pertemuan 1 ini adalah sebagai berikut:

a. Kegiatan Awal

a) Guru mengkondisikan kelas untuk belajar

b) Melakukan appersepsi

c) Guru menyampaikan tujuan pembelajaran dengan materi anggota keluargaku.

b. Kegiatan Inti

a) Siswa dibagi dalam kelompok 5 kelompok, setiap kelompok terdiri dari 4-5 orang.

b) Guru membuat potong-potongan kertas yang berisi jawaban atau soal sesuai materi yang telah diberikan.

c) Guru membagikan kartu kepada semua siswa, dan menjelaskan bahwa kartu tersebut ada yang dalam bentuk soal dan ada yang dalam bentuk jawaban

d) Guru menyuruh siswa dalam satu kelompok untuk duduk berhadapan

e) Guru menyarankan agar masing-masing kelompok untuk mencocokan semua kartu yang sesuai antara soal dan jawaban

f) Guru meminta siswa menemukan pasangan mereka. Jika ada yang sudah menemukan pasangan, minta mereka untuk duduk berdekatan, terangkan juga agar mereka tidak memberi tahu materi yang mereka dapatkan kepada teman yang lain

c. Kegiatan akhir

a) Guru dan siswa bersama-sama membuat kesimpulan

b) Guru memberikan evaluasi

c) Penutup

c. Hasil Observasi dan Refleksi

1) Siklus I dan II pada Pertemuan 1 dan 2

a) Aktivitas Guru

Tabel 2. Aktivitas Guru pada Setiap Siklus Pembelajaran

\begin{tabular}{|c|c|c|c|c|c|}
\hline \multirow{2}{*}{ No } & $\begin{array}{c}\text { Aktivitas } \\
\text { Guru }\end{array}$ & $\begin{array}{c}\text { Pertemuan } \\
\text { ke-1 }\end{array}$ & $\begin{array}{c}\text { Pertemuan } \\
\text { ke-2 }\end{array}$ & $\begin{array}{c}\text { Pertemuan } \\
\text { ke-1 }\end{array}$ & $\begin{array}{c}\text { Pertemuan } \\
\text { ke-2 }\end{array}$ \\
\cline { 2 - 6 } & $60 \%$ & $68,8 \%$ & $77,1 \%$ & $89,6 \%$ \\
\hline Persentase & Cukup & Baik & Baik & $\begin{array}{c}\text { Sangat } \\
\text { Baik }\end{array}$ \\
\hline Kreteria & \multicolumn{2}{c}{ Salklus II } \\
\hline
\end{tabular}

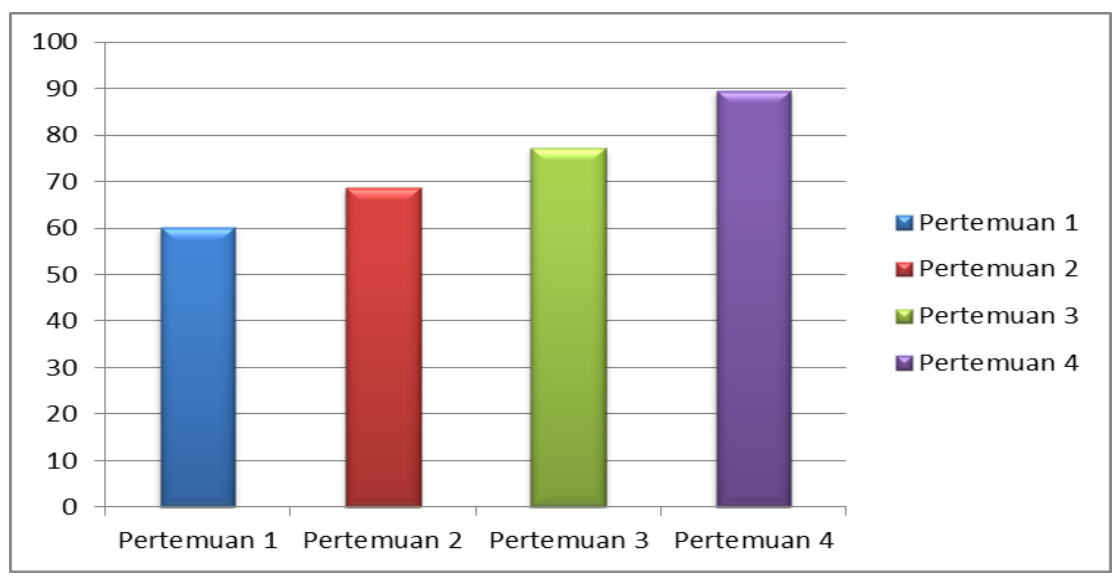

Gambar 1. Aktivitas Guru pada Setiap Siklus Pembelajaran 
b) Aktivitas siswa

\section{Aktivitas}

siswa

dalam pembelajaran yang dinilai oleh observer yang telah ditentukan selama melakukan kegiatan pembelajaran dengan mengggunakan lembar observasi yang telah disediakan. Aktivitas yang dinilai sesuai dengan kriteria yang disediakan pada lembar observasi. Aktivitas siswa pada pembelajaran siklus I dan II pada pertemuan 1 dan 2 dapat dilihat pada Tabel berikut:

Tabel 3. Aktivitas Siswa pada Setiap Siklus Pembelajaran

\begin{tabular}{|c|l|c|c|c|c|}
\hline \multirow{2}{*}{ No } & \multirow{2}{*}{ Kelompok } & \multicolumn{4}{|c|}{ Aktivitas Siswa } \\
\cline { 3 - 6 } & & \multicolumn{2}{|c|}{ Siklus I } & \multicolumn{2}{c|}{ Siklus II } \\
\cline { 3 - 6 } & & $\begin{array}{c}\text { Pertemuan } \\
\text { ke-1 }\end{array}$ & $\begin{array}{c}\text { Pertemuan } \\
\text { ke-2 }\end{array}$ & $\begin{array}{c}\text { Pertemuan } \\
\text { ke-1 }\end{array}$ & $\begin{array}{c}\text { Pertemuan } \\
\text { ke-2 }\end{array}$ \\
\hline 1. & Sangat Aktif (SA) & 0 & 0 & $27,28 \%$ & $63,63 \%$ \\
\hline 2. & Aktif (A) & $13,64 \%$ & $27,28 \%$ & $52,54 \%$ & $31,82 \%$ \\
\hline 3. & Cukup Aktif (CA) & $63,64 \%$ & $72,72 \%$ & $18,18 \%$ & $4,5 \%$ \\
\hline 4. & Kurang Aktif (KA) & $22,72 \%$ & 0 & $0,00 \%$ & 0 \\
\hline
\end{tabular}

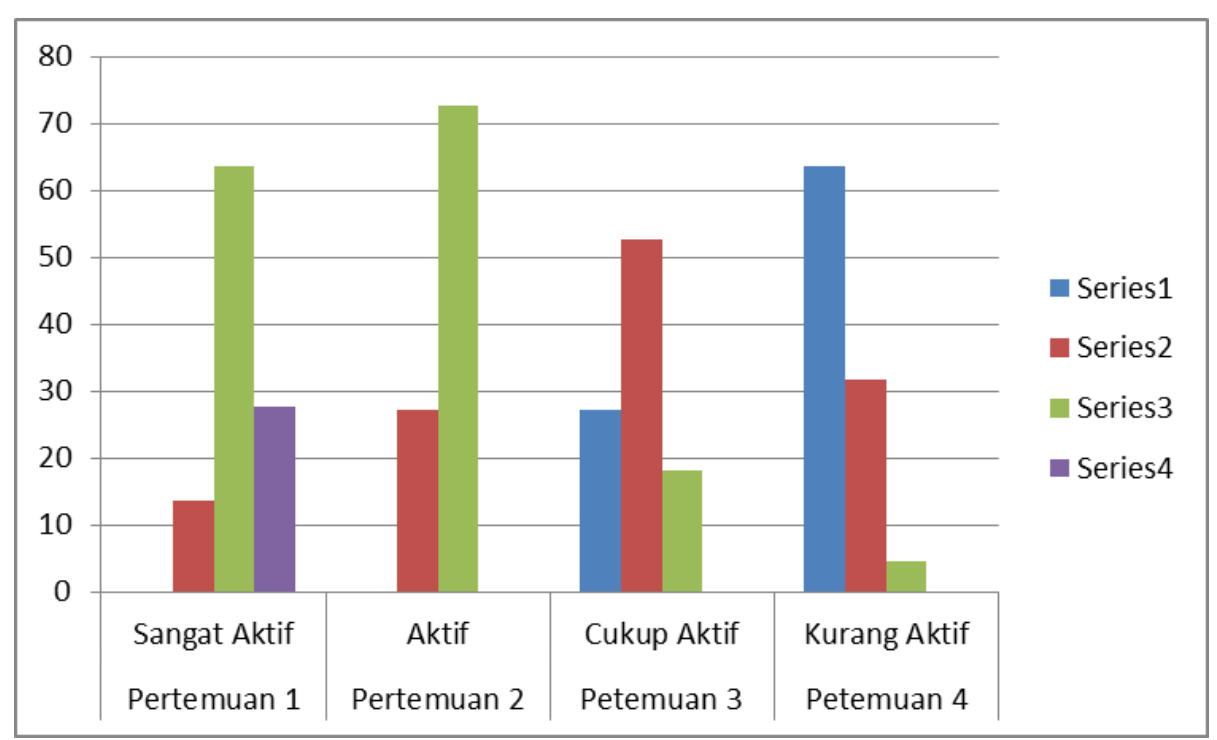

Gambar 2. Aktivitas Siswa pada Setiap Siklus Pembelajaran

c) Hasil Belajar Siswa pada Tema Keluargaku

Tabel 4. Nilai Kerja Kelompok Siswa pada Setiap Siklus Pembelajaran

\begin{tabular}{|c|c|c|c|c|c|}
\hline \multirow{2}{*}{ No. } & \multirow{2}{*}{ Kelompok } & \multicolumn{3}{|c|}{ Nilai Kerja Kelompok } \\
\cline { 3 - 6 } & & $\begin{array}{c}\text { Siklus I } \\
\text { ertemuan } \\
\text { ke-1 }\end{array}$ & $\begin{array}{c}\text { Pertemuan } \\
\text { ke-2 }\end{array}$ & $\begin{array}{c}\text { Pertemuan } \\
\text { ke-1 }\end{array}$ & $\begin{array}{c}\text { Pertemuan } \\
\text { ke-2 }\end{array}$ \\
\hline 1. & I & 60 & 80 & 100 & 100 \\
\hline 2. & II & 60 & 60 & 80 & 100 \\
\hline 3. & III & 60 & 60 & 80 & 100 \\
\hline 4. & IV & 80 & 100 & 100 & 100 \\
\hline 5. & V & 80 & 100 & 100 & 90 \\
\hline
\end{tabular}




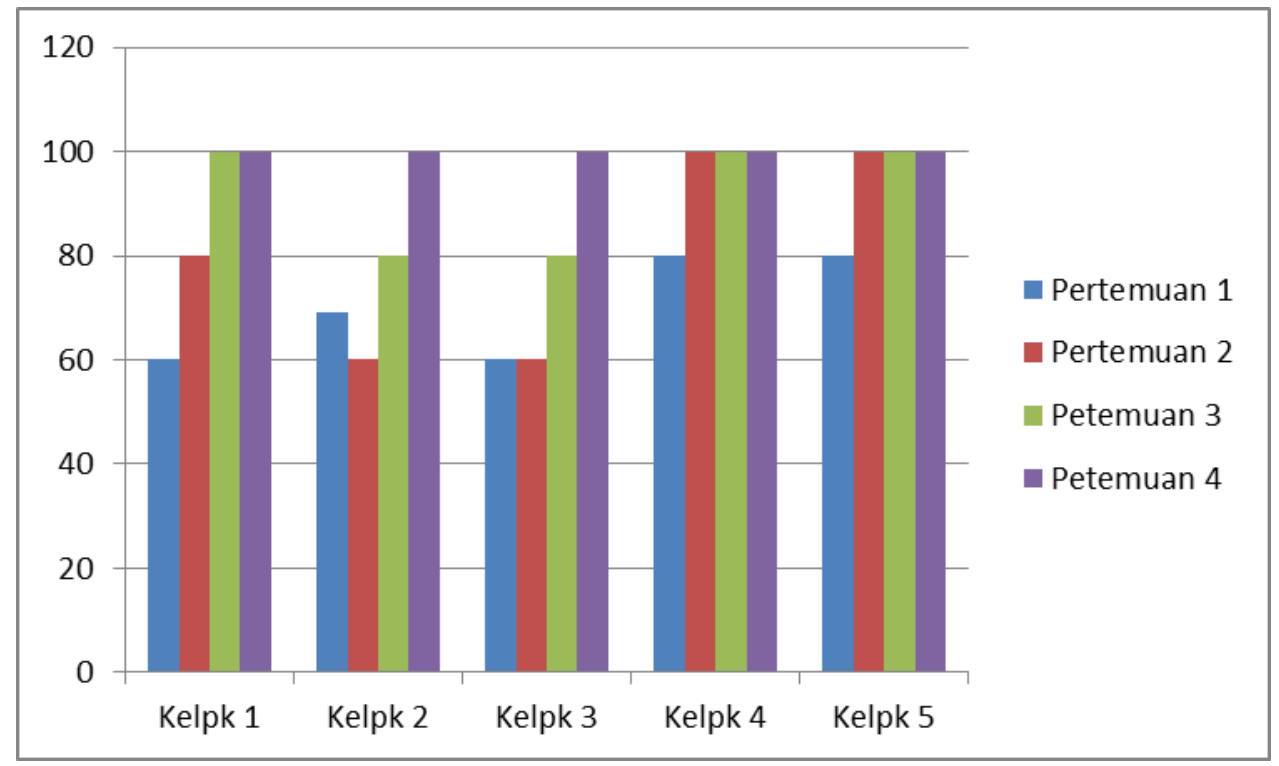

Gambar 2. Aktivitas Siswa pada Setiap Siklus Pembelajaran

Data hasil penelitian yang terekam dalam tabel dan diagram di atas menunjukkan terjadi peningkataan secara signifikan dari segi aktivitas guru, keaktifan siswa, serta hasil belajar siswa baik pada siklus 2 dibandingkan dengan siklus 1 . Model pembelajaran make a match dapat dilaksanakan secara efektif meskipun ada beberapa sisi yang masih memerlukan perbaikan-perbaikan. Akan tetapi secara keseluruhan dapat disimpulkan bahwa model pembelajaran kooperatif tipe Make a Match dapat meningkatkan hasil belajar siswa Kelas I Madrasah Ibtidaiyah Negeri 6 Tapin dalam materi tematik tentang keluargaku.

\section{PENUTUP}

Berdasarkan ulasan tersebut, maka dapat disimpulkan bahwa model pembelajaran make a match dapat meningkatkan aktivitas guru, siswa dan juga hasil belajar siswa kelas I MIN 6 Tapin pada tema keluargaku.

\section{DAFTAR PUSTAKA}

Arikunto, Suharjono, dan Supardi. 2014. Penelitian Tindakan Kelas. Bumi Aksara: Jakarta.
Dimyati dan Mudijono. 2009. Belajar dan Pembelajaran. Jakarta: PT. Rineka Cipta.

Djamarah, Syaiful Bahri dan Aswan Zain, 1997. Strategi Belajar Mengajar, Jakarta: Rineka Cipta.

Huda, Miftahul. 2013. Model-Model Pengajaran dan Pembelajaran. Yogyakarta: Pustaka Pelajar.

Iif, Khoiru Ahmadi dan Sofan Amri. 2011. Paikem Gembrot, Jakarta: PT Prestasib Pustakaraya.

Isjoni. 2012. Pembelajaran Kooperatif: Meningkatkan Kecerdasan Komunikasi antar Peserta Didik. Yogyakarta: Pustaka Pelajar.

Kadir, Abd. dan Hanun Asrohah. 2014. Pembelajaran Tematik, Jakarta: Raja Grapindo Persada.

Komulasari, Kokom. 2011. Pembelajaran Kontekstual, Bandung: PT. Rafika Aditama, 2011) (Bandung: PT. Rafika Aditama.

Lie, Anita. 2007. Cooperative Learning Mempraktikkan Cooperative Learning di Ruang-ruang Kelas. Jakarta: Gramedia.

Min, dkk. 2012. Teachers' Understanding and Practice towards Thematic Approach in Teaching Integrated Living Skills (ILS) in Malaysia. 
International Journal of Humanities and Social Science.

Munsyi, Abdul Kadir. 1991. Pedoman Mengajar (Bimbingan Praktek Untuk Calon Guru), Surabaya: Al Ikhlas.

Nahdiyatin, Siti Nur, 2006. Penerapan Metode Make a Match untuk Meningkatkan Hasil Belajar IPS pada Siswa Kelas III SDN 1 Jenangan Ponorogo. Jurnal Studi Sosial. 1(2): 81-90.

Permendikbud No. 57 Tahun 2014 tentang Kurikulum $2013 \quad$ Sekolah Dasar/Madrasah Ibtidaiyah. Online. http:// simpuh. kemenag.go.id /regulasi/ permendikbud_57_14.pdf

Rusman. 2011.Model-Model Pembelajaran, Jakarta: PT. Grafindo Persada.

Rusman. 2012.Model-Model Pembelajaran: Mengembangkan profesionalisme Guru, Jakarta: Rajawali Press.

Sabri, H. M. Alisuf. 2010. Psikologi Pendidikan Berdasarkan Kurikulum Nasional, (Jakarta: IAIN Fakultas Tarbiyah)

Sardiman, A. M.. 2005. Interaksi dan Motivasi Belajar Mengajar, Jakarta; PT Raja Grafindo Persada.

Slameto. 2001. Belajar dan Faktor-faktor yang Mempengaruhinya, Jakarta: Bina Aksara.
Solihatin, Raharjo Etin. 2007. Cooperative Learning. Jakarta: Bumi Aksara.

Sudjana, Nana. 1991. Model-model Mengajar CBSA .Bandung: Sinar Baru.

Suprijono, Agus. 2011. Cooperatif learning: Teori dan Aplikasi PAIKEM, Yogyakarta: Pustaka Pelajar.

Suryosubroto B. 2009. Proses Belajar Mengajar Disekolah, Jakarta: Reneka Cipta.

Trianto. 2010. Mendesain Model Pembelajaran Inovatif-Progresif, Jakarta: Kencana

Undang-Undang Sistem Pendidikan Nasional No 20 Tahun 2003, Jakarta: Biro Hukum dan Organisasi Sekretariat Jenderal Departemen Pendidikan dan Kebudayaan Nasional, Undang-Undang Sistem Pendidikan Nasioanl No 20 Tahun 2003

Usman, Moh. Uzer. 1992. Menjadi Guru Profesional, Bandung: PT. Remaja Rosdakarya.

Wahyono, Budi. 2019. Jalur dan Jenjang Pendidikan (Menurut UU Sisdiknas). Online http:// www. pendidikanekonomi.com/2012/12/ja lur-dan-jenjang-pendidikanmenurut-uu.html diakses 20 Maret 2019 